Archives of Agriculture and Environmental Science

\title{
Adoption of certain improved varieties of wheat (Triticum aestivum L.) in seven different provinces of Nepal
}

\author{
Sanjiv Subedi ${ }^{1^{*}}$ (D), Yuga Nath Ghimire ${ }^{1}$, Surya Prasad Adhikari ${ }^{1}$, Deepa Devkota ${ }^{1}$, Jiban Shrestha ${ }^{2}$, \\ Hema Kumari Poudel ${ }^{1}$ and Bidya Kiran Sapkota ${ }^{3}$ \\ ${ }^{1}$ Socioeconomics and Agricultural Research Policy Division, Nepal Agricultural Research Council (NARC), Khumaltar, Lalitpur, \\ NEPAL \\ ${ }^{2}$ Agriculture Botany Division, NARC, Khumaltar, Lalitpur, NEPAL \\ ${ }^{3}$ Agriculture and Forestry University, Rampur, Chitwan, NEPAL \\ *Corresponding author's E-mail: sanjiv.subedi@gmail.com
}

\section{ARTICLE HISTORY}

Received: 19 November 2019

Revised received: 29 November 2019

Accepted: 03 December 2019

\section{Keywords}

Adoption

Improved varieties

Indexing

Probit regression

Wheat productivity

\section{ABSTRACT}

This study used farm level data to analyze the adoption of improved wheat varieties in Nepal. The seven districts each having the highest wheat area coverage in their respective provinces was selected. Pre-tested interview schedule was used to collect the primary information. The relevant literatures were reviewed for secondary information. The simple random method of sampling was used and 651 samples were taken. Descriptive statistics, probit regression and indexing were applied. This study showed that $94.1 \%$ of the area was covered by the improved wheat varieties, while $3.3 \%$ by local and $2.6 \%$ by the Indian varieties. In addition, of the improved varieties, NL 297 had the highest area coverage (30.88\%) followed by Vijay (23.24\%), Gautam (12.95\%), NL 971 (8.94\%) and Aditya (5.34\%) respectively. Probit econometric model revealed that membership of organization (1\% level of significance), subsidy by the government ( $1 \%$ level), gender of the household head ( $5 \%$ level) and family member in foreign employment (10\%) significantly determined the adoption of improved wheat varieties developed after NARC establishment. The indexing identified and ranked- lack of availability of quality improved seeds $(I=0.75)$ as the first followed by poor availability of fertilizers (0.65), labour shortage (0.61), lack of proper irrigation (0.55) and lack of agricultural machines $(0.45)$ that were associated wheat production in study site. The concerned government institutions should assure the availability of quality improved seeds and fertilizers to the farmers; the subsidy on irrigation and agricultural machines allied with financial grant could attract the farmers towards wheat cultivation which ultimately contributes to increase wheat productivity.

(C)2019 Agriculture and Environmental Science Academy

Citation of this article: Subedi, S., Ghimire, Y.N., Adhikari, S.P., Devkota, D., Shrestha, J., Poudel, H.K. and Sapkota, B.K. (2019). Adoption of certain improved varieties of wheat (Triticum aestivum L.) in seven different provinces of Nepal. Archives of Agriculture and Environmental Science, 4(4) 404-409, https://dx.doi.org/10.26832/24566632.2019.040406

\section{INTRODUCTION}

Wheat (Triticum aestivum L.) is the third most important crop of Nepal which has the area of 706843 hectare (ha) (MoALD, 2019). It is the world's most favored staple food which is nutritious, easy to store and transport and can be processed into various types of food. Moreover, wheat is considered a good source of protein, minerals, B-group of vitamins and dietary fiber (Shewry, 2007; Kandel et al., 2018). The national produc- tion of wheat in the year 2017/18 is 1949001 metric ton ( $t$ ) and the productivity $2.75 \mathrm{t} / \mathrm{ha}$ (MoALD, 2019). More than $80 \%$ of wheat is grown in rice-wheat cropping pattern; in addition, it is a major winter cereal crop in Nepal (Kandel et al., 2018). The agriculture sector of Nepal, which shares $27.6 \%$ to the Gross Domestic Product (GDP) is greatly influenced by the change in national wheat production.

The area as well production of wheat in Nepal has been distinctly increased after the introduction of semi-dwarf varieties 
from Mexico, which has contributed to the food supply (Poudel et al., 2012; Pandey et al., 2019). Of the ecological regions, the Terai region is the major region where more than $60 \%$ of wheat is produced. The huge gap existing between the research and extension has limited the wheat productivity in Nepal; availability of improved seed and an improved package of practices could bridge this gap. It has been reported that there is a huge gap between yield potential and average national productivity Timsina et al. (2019). The 'yield gap' has been termed as the difference between actual yields in a region and agro-climatically achievable yields in the same region (Shrestha and Subedi, 2019).

More than 40 improved varieties of wheat have been recommended by Nepal Agricultural Research Council (NARC) for different ecological zones of them, 26 are for Terai and 17 for hills. Also, of total improved varieties released, only 30 varieties are under cultivation while 13 have been denotifed (Timsina et al., 2018). The wheat varieties, NL 297, UP262 and RR21 were developed before NARC establishment which are disease susceptible and have been less prioritized for seed production by the government; however, these varieties are yet common among the wheat growers of Nepal. Among these three unprioritized varieties, NL 297, and UP262 have been recommended for Terai whereas RR 21 has been recommended for Terai and mid-hills. The adoption of high yielding improved wheat varieties which are climate suitable and resistant to disease and drought could increase the national production and productivity. Thakur et al. (2007) revealed that the adoption of much improved technologies by the farmers have significant effect in rate of change in wheat productivity.

The national commodity research program under NARC has been established in Bhairahawa, Rupandehi district named National Wheat Research Program (NWRP), Bhairahawa, Rupendehi. NWRP has developed improved wheat varieties which are high yielding and disease resistant as well. The improved varieties such as: Gautam, Vijay, Bhrikuti, NL 971, Tilottama, Aditya, WK1204, BL 1473, Dhaulagiri, Danphe etc. which are popular among the Nepalese farmers has been developed by NWRP, NARC. It is very necessary to figure out the status of coverage of these improved varieties. Moreover, the estimation of production and productivity of wheat in Nepal, highlighting the status of different varieties in major wheat growing districts of different provinces is necessary. Also, identification of major five improved wheat varieties grown in Nepal need to be done. Apart from this, identifying the factors affecting the adoption of improved varieties is necessary. There are limited studies on assessment of wheat production in Nepal, identifying the socio-economic and farm characteristics that affect the wheat production. Also, it is necessary to explore the major problems that are associated with the wheat production with their respective rank. In this context, to address these research gaps, this research is designed to investigate the adoption of improved varieties of wheat in seven selected provinces of Nepal.

\section{MATERIALS AND METHODS}

Study area, sample size and data collection technique

Altogether, seven districts: Sunsari (Harinagar, Gadi, Ramdhuni), Bara (Simraungadh, Kalaiyamai, Jeetpur Simra), Kavrepalanchok (Mandandeupur, Budhakhani, Ritthe, Khatechaur), Baglung (Baglung municipality, Galkot), Rupandehi (Siyari, Mayadevi, Tilottama, Omsatiya, Suddhodhan) Dailekh (Dhungeshwor, Narayan, Dullu, Guras) and Kailali (Godawari, Fulbari, Dhangadhi) from seven provinces, each having the highest wheat area coverage in their respective provinces were selected (Figure 1). The primary information was collected by using the pre-tested interview questionnares. Also the two Key Informant Surveys were performed. The secondary information was collected by reviewing the literatures that were relevant to this study. The selection of the survey areas in the selected districts were on the basis of the consultation that was performed with Agriculture Knowledge Centre and agricultural officials of the local government. All total, 651 samples were selected for this study after omitting the outliers and incomplete responses.

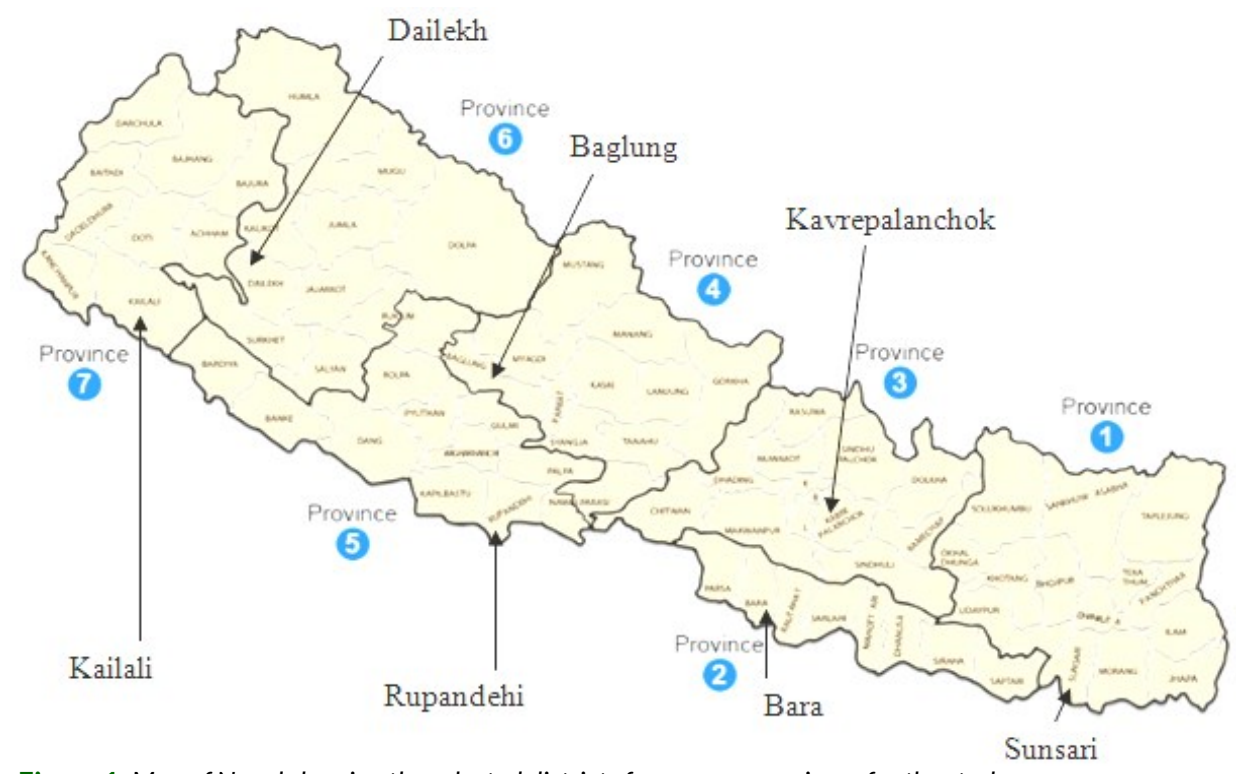

Figure 1. Map of Nepal showing the selected districts from seven provinces for the study. 
Identifying the determinant factors that affects the decision to adopt improved wheat varieties developed after NARC establishment

To identify the factors that affect the decision to adopt improved wheat varieties developed after NARC establishment, a probit regression model was used. Reviewing the literatures, the probit model has been used to determine the factors affecting the adoption of improved technology (Hattam, 2006). Moreover, Kafle (2010) also used probit model to determine the factors affecting the decision to adopt improved maize varieties. The characteristic feature of the Probit model is that in this model, the effect of independent variables on dependent variables is non-linear. This statistical establishes a relation between probability values and explanatory variables model that ensures the probability value remains between 0 and 1 . Probit model is also adopted by Shrestha et al. (2018) for assessing determinants of household food insecurity. The social sciences statistical package (STATA) was used for the econometric analysis (STATA version 16 manual; Greene, 2011). The statistical description of the different independent variables used in this model is shown below in the Table 1.

The identify the factors affecting farmers' decisions to adopt improved wheat varieties developed after NARC establishment; the following probit model has been used.

$\operatorname{Pr}$ (adoption of improved wheat varieties developed after NARC establishment $=1)=f\left(b_{0}+b_{1} X_{1}+b_{2} X_{2}+b_{3} X_{3}+b_{4} X_{4}+b_{5} X_{5}+\right.$ $\left.b_{6} x_{6}+b_{7} x_{7}+b_{8} x_{8}+b_{9} x_{9}\right)$

Where, $\operatorname{Pr}=$ Probability score for adoption of varieties developed after NARC establishment.

\author{
$\mathrm{X}_{1}=$ subsidy (Dummy) \\ $\mathrm{X}_{2}=$ membership (Dummy) \\ $\mathrm{X}_{3}=$ if any family member is in foreign employment (Dummy) \\ $\mathrm{X}_{4}=$ gender of the household head (decision maker) (Dummy) \\ $\mathrm{X}_{5}=$ age of the household head \\ $X_{6}=$ number of schooling years of the household head \\ $X_{7}=$ number of family members involved in agriculture \\ $\mathrm{X}_{8}=$ total number of family members
}

Where, $b_{1}, b_{2} \ldots b_{9}=$ Probit coefficient, $b_{0}=$ Regression coefficient

Problems/constraints associated with wheat production

To explore the major problems associated with the wheat production, indexing/scaling technique was applied and the index was calculated. Subedi et al. (2019) also used the scaling technique to identify the constraints associated with the potato production in Terai region of Nepal. The weighted indexes were calculated and the problems were ranked by using five point scales based on their responded frequencies. The formula that was used to determine the index for intensity of various problems was:

$$
\mathrm{I}_{\text {prob }}=\sum \frac{\text { Sifi }}{N}
$$

where, $I_{\text {prob }}=$ index value for severity or intensity of problem

$\Sigma=$ summation

$\mathrm{S}_{i}=$ scale value at $i^{\text {th }}$ intensity/severity

$f_{i}=$ frequency of the $i^{\text {th }}$ severity

$\mathrm{N}=$ total no. of the respondents $=\sum \mathrm{f}_{\mathrm{i}}$

Where, $I_{\text {prob }}=$ index, $0<1<1$

This above formula was also applied by Shrestha and Shrestha (2017) to rank the problems associated with maize seed production (Figure 2).

Table 1. Statistical description of the variables used in the probit regression model.

\begin{tabular}{|c|c|c|c|}
\hline Variables & Description & Value & Expected sign \\
\hline Subsidy & Government subsidy in inputs & $\begin{array}{l}\text { If subsidy provided }=1 \text {, otherwise }=0 \\
\text { (Dummy) }\end{array}$ & + \\
\hline Membership & Membership of any organization & $\begin{array}{l}\text { If had membership }=1 \text {, otherwise }=0 \\
\text { (Dummy) }\end{array}$ & + \\
\hline Abroad & If family member is in foreign employment & Abroad yes $=1$, otherwise $=0$ & $+/-$ \\
\hline Gender & Gender of the household head & Male $=1$, otherwise $=0$ & $+/-$ \\
\hline Age & Age of the household head & Years (in number) & $+/-$ \\
\hline Edu & Number of schooling years & Years (in number) & $+/-$ \\
\hline ag_inv & Number of family members involved in agriculture & Persons (in number) & + \\
\hline f_size & Number of family members & Persons (in number) & $+/-$ \\
\hline
\end{tabular}

+ indicates positive sign; - indicates negative sign.

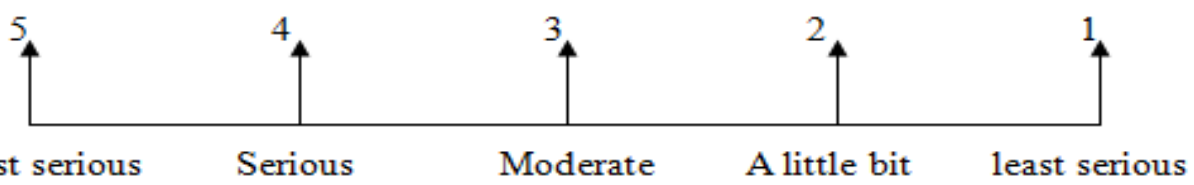

Figure 2. Scale of rating for the problems associated with wheat production. 


\section{RESULTS AND DISCUSSION}

\section{Varietal distribution of wheat in Nepal}

This study revealed that $94.1 \%$ of the area was covered by the improved wheat varieties, while $3.3 \%$ by local and $2.6 \%$ by the Indian varieties. The average productivity of wheat in the study area was calculated 2.62 t/ha; improved (2.91), Indian (2.97) and local (1.99). Also, the study showed that of the total improved varieties coverage, $35.67 \%$ is occupied by the three varieties ( $\mathrm{NI}$ 297, UP 262 and RR 21 that were release before NARC establishment, with the average productivity $2.88 \mathrm{t} / \mathrm{ha}$; however, these varieties are not recommended by the government for seed production. The majority area (64.33\%) has been covered by the improved varieties developed by NARC. There are Gautam, Vijay, NL 971, BL1473, Aditya, Bhrikuti, WK1204, Danphe, Dhaulagiri, and Annapurna with the average productivity $2.93 \mathrm{t} /$ ha (Field survey, 2019). Cent percent cultivated area is covered by the improved varieties in Sunsari and Baglung while all other districts has good majority of improved varieties. Furthermore, of the improved varieties, NL 297 has the highest area coverage (30.88\%) followed by Vijay (23.24\%), Gautam (12.95\%), NL 971 (8.94\%) and Aditya (5.34\%), respectively. It is better illustrated in the Figures 3 and 4 .

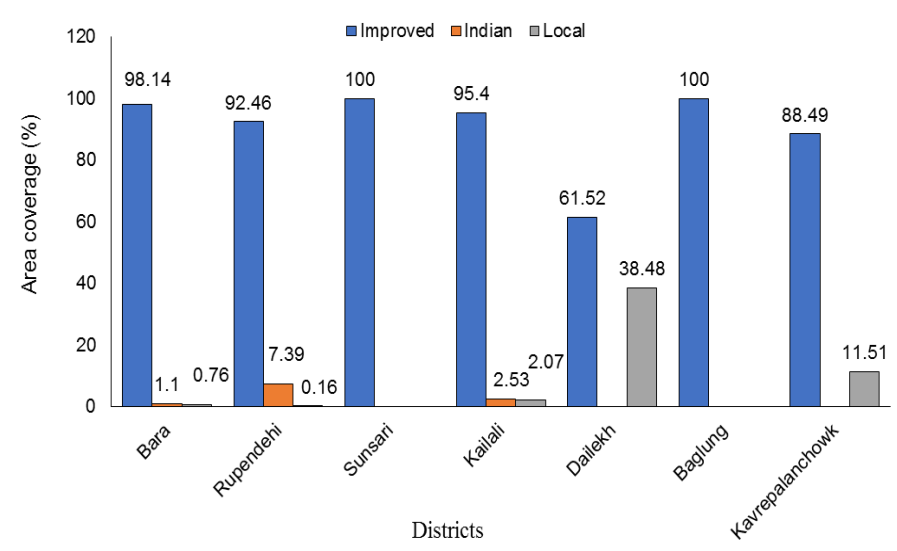

Figure 3. Area coverage of different wheat varieties in the selected districts.

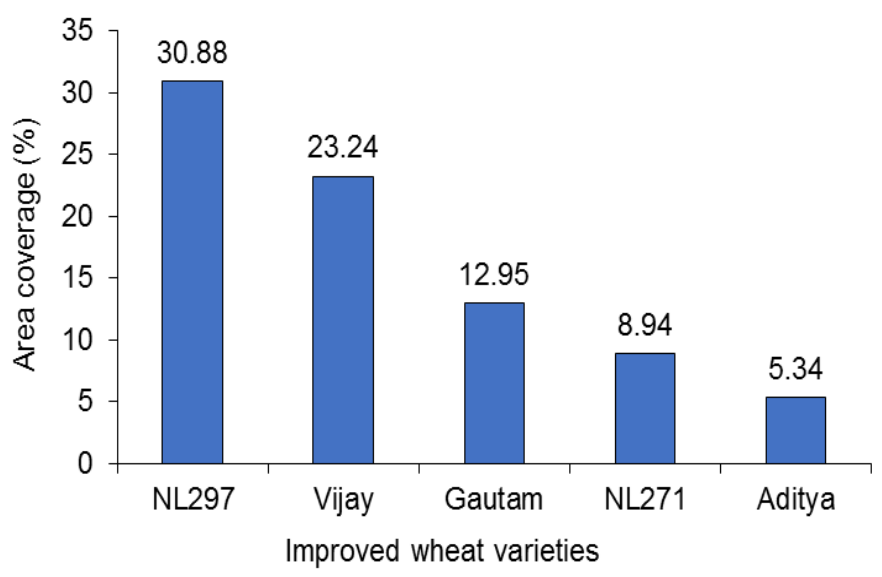

Figure 4. Area coverage of different improved wheat varieties in the study area.
Determination of factors affecting the decision to adopt improved wheat varieties

A probit regression model was used to identify the factors affecting the decision to adopt improved wheat varieties developed after NARC establishment where the binary response of the 651respondents was coded as; adopters $=1$ and 0 otherwise. The Wald test $\left(\mathrm{LR} \mathrm{chi}{ }^{2}\right.$ ) revealed that the model has good explanatory power at the $1 \%$ level. This means, all the independent or explanatory variables included in the model jointly influence the probability of adoption of improved wheat varieties developed after NARC establishment by the farmers. The probit model estimated the pseudo $\mathrm{R}^{2} 0.05$ which implies, the variables included in the model explains $5 \%$ of the probability of farm household's decisions to adopt or not to adopt wheat varieties developed after NARC establishment. The area under ROC curve for the regression has been estimated 0.66 which revealed that the model presents adequate discrimination. Also, probit regression analysis showed that the four variables: government subsidy in inputs, membership of any organization, family member in foreign employment and gender of the household head significant affects the decision to adopt the improved varieties developed by NARC (Table 2). Furthermore, to interpret the model, the marginal effects were driven from the regression coefficients, calculated from the partial derivatives as a marginal probability which is shown in Table 2.

The farmers who had membership of any organization had $15 \%$ more probability for adoption of improved varieties released after NARC establishment as compared to farmers having no membership. This was significant at $1 \%$ level of significance (Table 2). In line of this finding, Subedi and Dhakal (2015) also stated that there is positive relationship between the adoption of poultry manure technology in agriculture and membership in any organization or cooperatives. In a like manner, Uaiene et al. (2009) stated that individual decisions are affected by social network effects, and that in the context of agricultural Innovations, farmers interact, share and learn from each other. Similarly, the probability of adoption of improved varieties released after NARC establishment is $17 \%$ more for the farmers at $1 \%$ level of significance, which had got subsidy in inputs for wheat production from the government as compared to farmers who hadn't got (Table 2). The subsidy in inputs supports the cost of production which encourages the farmers for agricultural production. In line of this finding, Mason and Smale (2013) also revealed that the government subsidies could encourage the farmers to adopt the new technology.

Furthermore, the gender of the household head was found to be significant (at $5 \%$ level of significance) but negatively related to the adoption of improved wheat varieties developed by NARC. The probability of adoption of improved wheat varieties decreased by $11 \%$ for the households having male household head as compared to households having female household head (Table 2). The female who had headed their household might have got opportunity to participate in agricultural training and discussions which could have motivated them in adoption of 
new technology. Aregu et al. (2011) also reported that women participation and gender inclusion in the workshop and even the training related to seed production, nursery management and fertilizer treatments has been encouraged by the government. In a like manner, Tavya et al. (2013) stated that the technological innovation if properly understood from the gender perspective, increment of the agricultural productivity will be encouraged.

Lastly, the probability of adoption of improved varieties released after NARC establishment is $8 \%$ more for the households whose family member is in foreign employment as compared to the households having no family in foreign employment. It has been found significant at $10 \%$ level of significance (Table 2). The annual household income of the household would be obviously good through remittance if someone from the household is in foreign employment. In addition, if the household have good economic situation, it might be convinced to take risk in adoption of new technology. Gbetibouo (2009) and Deressa et al. (2009) also supported the argument that increase in annual household income increases the probability of adoption of new technology as the ability to bear risk increases and comparatively have better economic position to adopt the new technology.

Assessment of problems/constraints associated with the wheat production

When the wheat growing farmers were asked to rank the problems related to wheat production, they ranked- lack of availability of quality improved seeds as the major problem followed by poor availability of fertilizers. Similarly, labour shortage, lack of proper irrigation and lack of agricultural machines were the third, fourth and fifth problems respectively as per farmer's ranking (Table 3). It has been reported that the lack of availability of quality seeds and other inputs such as fertilizers and farm machinery are hindrance to increase the maize production and productivity (Hailu, 1992). Hintze et al. (2003) also reported that the increment in production and income are assisted by the availability of technical assistance and adequate irrigation facilities. Furthermore, Paudyal (2001); Shrestha and Timsina (2011) also stated that the seed quality, irrigation facilities and disease pest infestation has significant effect on the yield.

Table 2. Factors that affects the decision to adopt improved wheat varieties developed after NARC establishment.

\begin{tabular}{lccccc}
\hline Variables & Coefficients & $\mathbf{P}>|\mathbf{z}|$ & Standard error & dy/dx $^{\mathbf{b}}$ & \multicolumn{1}{c}{ S.E $^{\mathbf{b}}$} \\
\hline Subsidy & $.659^{*}$ & 0.010 & .257 & .171 & .050 \\
Membership & $.449^{* * *}$ & 0.000 & .109 & .146 & .035 \\
Abroad & $.248^{*}$ & 0.065 & .134 & .077 & .040 \\
Gender & $-.376^{* *}$ & 0.031 & .174 & -.001 & .046 \\
Age & -.002 & 0.737 & .005 & .006 & .002 \\
Edu & -.020 & 0.155 & .014 & .001 & .004 \\
ag_inv & -.004 & 0.908 & .033 & .011 \\
f_size & .012 & 0.492 & .018 & .006 \\
Constant & .748 & 0.011 & .293 & & \\
\hline
\end{tabular}

*** $1 \%$ level of significance; ${ }^{* *} 5 \%$ level of significance; ${ }^{*} 10 \%$ level of significance. ${ }^{b}$ Marginal change in probability evaluated at the sample means.

\section{Summary statistics}

Number of observation $(\mathrm{N})$

Log likelihood

LR chi ${ }^{2}$ (8)

Pseudo $\mathrm{R}^{2}$

Predicted probability (adoption)

Goodness of fit test

Area under ROC curve

\author{
651 \\ $-361.60151$ \\ $40.60^{* * *}\left(\right.$ Prob $\left.>\mathrm{chi}^{2}=0.0000\right)$ \\ 0.05 \\ 0.74 \\ Pearson $\mathrm{chi}^{2}(635)=639 \cdot 14 \cdot$ Prob $\mathrm{chi}^{2}=0.4465$ \\ 0.66
}

Source: Field survey, 2019

Table 3. Problems associated with the wheat production (Source: Field survey, 2019).

\begin{tabular}{llll}
\hline S.N. & Problems & Index value & Rank \\
\hline 1 & Lack of quality improved seeds & 0.75 & I \\
2 & Poor availability of fertilizers & 0.65 & II \\
3 & Labour shortage & 0.61 & III \\
4 & Lack of proper irrigation & 0.55 & IV \\
5 & Lack of agricultural machines & 0.45 & $\mathrm{~V}$ \\
\hline
\end{tabular}




\section{Conclusion}

This study revealed that around $94 \%$ of the area has been covered by the improved wheat varieties. Also, the variety NL 297 , government, was found to have the highest area coverage (30.88\%). This showed the necessity of proper extension programs to promote the adoption of recently released high yielding and disease resistant varieties developed by NARC. The involvement of farmer in any organization, moreover, the female household heads should be promoted as it has been found to be significant in the adoption of improved varieties developed by NARC. Giving aggressive subsidies, providing the grants to support the annual household income for agricultural investment could promote the adoption of recently released high yielding varieties of NARC. Also, the favorable environment should be created for the remittance earning households in adoption of new technology through technical support and providing membership in farmers' group. Furthermore, this study revealed that lack of proper access to quality seeds and fertilizers, timely unavailability of human labor, inadequate irrigation facilities and having no proper access to agricultural machines has been explored as the major problems associated with the wheat production. The concerned government institutions should assure the availability of quality improved seeds and fertilizers to the farmers; in addition, subsidy on irrigation and agricultural machines allied with financial grant could attract the farmers towards wheat cultivation which ultimately contributes to increase the wheat productivity of the nation.

\section{ACKNOWLEDGEMENTS}

The authors would like to express their profound gratitude to the seniors and colleagues of Nepal Agriculture Research Council (NARC) and the officials of Agriculture Knowledge Centre and Local government for their cooperation and support to carry out this study.

\section{Conflict of interest}

The authors declare that there is no conflict of interest regarding publication of this manuscript.

Open Access: This is an open access article distributed under the terms of the Creative Commons Attribution 4.0 License, which permits unrestricted use, distribution, and reproduction in any medium, provided the original author(s) if the sources are credited.

\section{REFERENCES}

Aregu, L., Puskur, R. and Sambrook, C.B. (2011). The role of gender in crop value chain in Ethiopia. Paper presented at the Gender and Market Oriented Agriculture (AgriGender 2011) Workshop, Addis Ababa, Ethiopia, $31^{\text {st }}$ January- $2^{\text {nd }}$ February 2011. Nairobi, Kenya.

Deressa, T.T., Hassan, R.M., Ringler, C., Alemu, T. and Yusuf, M. (2009). Determinants of farmer's choice of adaptation methods to climate change in the Nile Basin of Ethiopia. Global Environment Change, 19(2): 248-255, https://doi.org/10.1016/j.gloenvcha.2009.01.002

Gbetibouo, G.A. (2009). Understanding farmer's perceptions and adaptations to climate change and variability. The case of Limpopo Basin, South Africa.
IFPRI Discussion Paper 00849.Environment and production Technology Division. International Food Policy Research Institute. Retrieved on $12^{\text {th }}$ January 2013 from www.ifpri.org/pubs/otherpubs.htm\#dp

Greene, W.H. (2011), Econometric Analysis, 7th Edition, Prentice Hall, New Jersey, USA. Hailu, G. (1992). Availability and use of seed in Ethiopia. Program support unit, Canadian International Development Agency, Addis Ababa, Ethiopia.

Hattam, B.C. (2006). Barriers to the adoption of organic agriculture: An investigation using the Theory of planned behaviour.

Hintze, L.H., Renkow, M. and Sain, G. (2003). Variety characteristics and maize adoption in Honduras. Journal of Agricultural Economics, 29: 307-317.

Kafle, B. (2010). Determinants of adoption of improved Maize varieties in Developing Countries: a Review. International Research Journal of Applied and Basic Sciences, 1(1): 1-7, https://doi.org/10.1111/j.1477-9552.2004.tb00115.x

Kandel, M., Bastola, A., Sapkota, P., Chaudhary, O., Dhakal, P. and Shrestha, J. (2018). Analysis of genetic diversity among the different wheat (Triticum aestivum L.) Genotypes. Turkish Journal of Agricultural and Natural Sciences, 5(2): 180-185.

Mason, N.M. and Smale, M. (2013). Impacts of subsidized hybrid seed on indicators of economic wellbeing among smallholder maize growers in Zambia. Agricultural Economics, 44(6): 659-670.

MoALD. (2019). Statistical Information on Nepalese Agriculture 2017/2018. Agri Statistics Section, Monitoring, Evaluation and Statistics Division, Ministry of Agricultural Development, Singha Durbar, Kathmandu, Nepal.

Pandey, D., Chaudhari, H.K., Upadhyay, S.R., Gautam, N.R., Ghimire, B.R., Shrestha, J. and Thapa, D.B. (2019). Participatory on-farm evaluation of wheat varieties. Journal of Agriculture andNatural Resources, 2(1): 312-321.

Poudel, D.C., Shrestha, J., Hamal, G.B., Aryal, A., Adhikary, B.H., Rijal, T.R. and Tripathi, M.P. (2012). On-farm evaluation of wheat genotypes at outreach sites of NMRP Rampur, Chitwan, Nepal. In: Paudel MN and Kafle B (eds.), Proceeding of the $10^{\text {th }}$ National Outreach Research Workshop 27-28 February, 2012, Outreach Research Division, NARC, Khumaltar. pp. 54-61.

Paudyal, K.R., Ransom, J.K., Rajbhandari, N.P., Adhikari, K., Gerpacio, R.P. and Pingali, P.L. (2001). Maize in Nepal: Production Systems, Constraints, and Priorities for Research. Kathmandu: NARC and CIMMYT.

Shewry, P.R. (2007). Improving the protein content and composition of cereal grain. Journal of Cereal Science, 46(3): 239-250.

Shrestha, A., and Shrestha, J.(2017). Production, problems and decision making aspects of Maize seed producers in Banke District, Nepal. Azarian Journal of Agriculture, 4(6): 212-216.

Shrestha, J. and Timsina, K.P. (2011). Agronomic performance and economic analysis of maize (Zea mays L.) under different plant geometry and nitrogen rates in Chitwan, Nepal. Nepalese Journal of Agriculture Science,9: 5-13.

Shrestha, J. and Subedi, S. (2019). Improving crop productivity through sustainable intensification. South Asian Research Journal of Agriculture and Fisheries, 1(1): 8-11.

Shrestha, K. P., Giri, R., Mishra, S. and Shrestha, J. (2018). Status of household food insecurity in Bajura district of Nepal. Journal of Bioscience and Agriculture Research, 18(02): 1531- 1538.

Subedi, S. and Dhakal, D. (2015). Economics of poultry manure as an alternative to chemical fertilizer for agricultural production in Nepal. Journal of Institute of Agriculture and Animal Sciences, 33-34: 259-268.

Subedi, S., Ghimire, Y.N., Gautam, S., Poudel, H.K. and Shrestha, J. (2019). Economics of potato (Solanum tuberosum L.) production in terai region of Nepal. Archives of Agriculture and Environmental Science, 4(1): 57-62, https://dx.doi.org/10.26832/24566632.2019.040109

Tavya, S., Abdelali-Martini, M., Aw-Hassan, A., Rischkowsky, B., Tibbo, M. and Rizvi, J. (2013). Gender Roles in Agriculture: The Case of Afghanistan. Indian Journal of Gender Studies, 20(1): 111-134, https://dx.doi.org/10.1177/0971521512465939

Thakur, N.S., Paudel, M.N., Gauchan, D. and Shrestha, B. (2007). Measuring returns from improved rice, maize and wheat research in Nepal. Nepal Agriculture Research Journal, 8: 103-112.

Timsina, K.P., Ghimire, Y.N., Gauchan, D., Subedi, S. and Adhikari, S.P. (2018). Lessons for promotion of New Agricultural Technology: A Case of Vijay Wheat Variety in Nepal. Agriculture and Food Security, 7: 63.

Timsina, K.P., Gairhe, S., Koirala, P. and Shrestha, J. (2019). Investment on wheat research and its effect: A case of Nepal. Agriculture Science and Technology, 11 (2):138-143

Uaiene, R., Arndt, C. and Masters, W. (2009). Determinants of Agricultural Technology Adoption in Mozambique. Discussion papers No. 67E. 